\title{
EFISIENSI TEKNIS USAHATANI JAGUNG DI KECAMATAN REMBOKEN KABUPATEN MINAHASA
}

\author{
Juliana Ruth Mandei
}

\begin{abstract}
The study was conducted in order to determine the efficiency of maize farming techniques in District Remboken and analyze the determinants of the level of technical efficiency of maize farming in the district Remboken. Sampling was done by using the method of Sampling Cluster, specifically three farmers groups program participant Integrated Crop Management Field School (SLPTT) and three farmers group who are not participants SLPTT. The variables measured in this study is the production $(\mathrm{kg} /$ season), land planted with maize (ha), amount of labor used (HOK), Total Urea is used ( $\mathrm{kg}$ ), amount of fertilizer used Phonska ( $\mathrm{kg}$ ), amount of seed used ( $\mathrm{kg}$ ) and the amount of pesticides used (ltr). The variables used to see the factors affecting technical efficiency is age measured in years farmers, farmer education levels measured by using dummy variables, and the number of dependents of farmers. To see the technical efficiency of maize farming using frontier production function and to analyze the factors affecting technical efficiency of farming corn used multiple regression analysis with OLS. The results showed that maize production was significantly affected by labor, seeds and herbicides, Most cultivated maize farming has been technically efficient farmers and the level of technical efficiency of farmers follow SLPTT lower than farmers who do not follow SLPTT. The number of dependents and education levels significantly affect the level of technical efficiency of maize farming in the district Remboken. Necessary to reformulate the model of Integrated Crop Management Field School is more effective to improve the ability of farmers to manage their farming.
\end{abstract}

Keywords : Maize farming, technical efficiency, Remboken District

\section{ABSTRAK}

Penelitian dilakukan dengan tujuan untuk mengetahui efisiensi teknik usahatani jagung di Kecamatan Remboken dan menganalisis faktor penentu tingkat efisiensi teknik usahatani jagung di Kecamatan Remboken. Penarikan sampel menggunakan metode cluster sampling, yaitu Tiga kelompok tani peserta Sekolah Lapang Pengelolaan Tanaman Terpadu (SLPTT) dan tiga kelompok tani bukan peserta SLPTT. Variabel-variabel yang diukur dalam penelitian ini adalah Produksi (kg/musim tanam), Lahan yang ditanami jagung (ha), Jumlah Tenaga kerja yang digunakan (HOK), Jumlah Pupuk Ureayang digunakan (kg, Jumlah Pupuk Phonska yang digunakan ( $\mathrm{kg})$, Jumlah Benih yang digunakan (kg) dan Jumlah Pestisida yang digunakan (ltr). Variabel-variabel yang digunakan untuk melihat factor-faktor yang mempengaruhi efisiensi teknis adalah umur petani yang diukur dalam tahun, tingkat pendidikan petani yang diukur dengan menggunakan variable dummy, dan jumlah tanggungan keluarga . Untuk melihat efisiensi teknis usahatani jagung menggunakan fungsi produksi frontier dan untuk melihat faktor-faktor yang mempengaruhi efisiensi teknis usahatani jagung digunakan analisis regresi berganda dengan metode OLS. Hasil penelitian menunjukkan bahwa Produksi Jagung secara nyata dipengaruhi oleh tenaga kerja, benih dan herbisida, Sebagian besar usahatani jagung yang diusahakan petani telah efisien secara teknis dan tingkat efisiensi teknis petani peserta SLPTT lebih rendah dari petani yang bukan peserta SLPTT. Jumlah tanggungan dan tingkat pendidikan secara signifikan mempengaruhi ting- 
kat efisiensi teknis usahatani jagung di Kecamatan Remboken. Perlu merumuskan kembali model Sekolah Lapang Pengelolaan Tanaman Terpadu yang lebih efektif untuk meningkatkan kemampuan petani dalam mengelola usahataninya.

Kata kunci: Usahatani Jagung, efisiensi tehnis, Kecamatan Remboken

\section{PENDAHULUAN}

Jagung merupakan salah satu komoditi tanaman pangan yang penting setelah padi karena selain sebagai sumber kalori atau makanan pengganti beras, jagung itu juga digunakan sebagai pakan ternak. Kebutuhan jagung akan terus meningkat dari tahun ketahun sejalan dengan peningkatan taraf hidup ekonomi masyarakat dan kemajuan industri pakan ternak sehingga perlu upaya peningkatan produksi . Dalam meningkatkan produksi jagung, penggunaan faktor produksi dan penerapan teknologi memegang peranan penting. Kurang tepatnya penerapan teknologi akan mengakibatkan rendahnya produksi dan tingginya biaya usahatani. Sehubungan dengan hal tersebut pemerintah mengadakan program Sekolah Lapang Pengelolaan Tanaman Terpadu (SLPTT).

Kecamatan Remboken merupakan salah satu daerah produksi Jagung di kabupaten Minahasa yang diberi kesempatan untuk merealisasikan program Sekolah Lapang Pengelolaan Tanaman Terpadu (SLPTT), tapi tidak semua petani bisa mengikuti program ini. Program ini bertujuan untuk meningkatkan kemandirian pangan nasional melalui usaha peningkatan produksi pangan nasional, khususnya padi, jagung dan kedelai. Pengembangan SLPTT dilakukan dengan memberi pengajaran pada petani mengenai pemberian benih, pupuk, pengendalian hama terpadu, sekolah lapang iklim dan teknologi budidaya (Apriyantono, 2008). Olehkarenanya diharapkan dengan program ini kinerja usahatani jagung dari petani peserta program akan lebih baik dari yang tidak mengikuti program ini. Salah satu kinerja usahatani yang sering menjadi indikator adalah efisiensi teknik. Suatu usahatani dapat dikatakan efisien secara ekonomi jika efisiensi secara teknik telah dicapai.

Berdasarkan latar belakang tersebut maka peneliti merasa tertarik untuk mengetahui efisiensi teknik usahatani Jagung di Kecamatan Remboken serta faktor-faktor yang mempengaruhinya.

\section{Perumusan Masalah}

Program Sekolah Lapang Pengelolaan Tanaman Terpadu (SLPTT) bertujuan untuk meningkatkan produksi tanaman pangan termasuk tanaman Jagung.

Berdasarkan hal tersebut maka yang menjadi rumusan masalah dalam penelitian ini adalah bagaimana efisiensi teknis usahatani Jagung dari petani peserta dan bukan peserta SLPTT di Kecamatan Remboken dan faktorfaktor apa yang mempengaruhi efisiensi teknis usahatani jagung di Kecamatan Remboken?

\section{Tujuan Penelitian}

1. Untuk mengetahui efisiensi teknis usahatani jagung di Kecamatan Remboken.

2. Untuk mengetahui faktor penentu efisiensi teknik usahatani jagung di Kecamatan Remboken. 


\section{TINJAUAN PUSTAKA}

\section{Konsep Efisiensi}

Dalam terminologi ilmu ekonomi, maka pengertian efisien ini dapat digolongkan menjadi 3 macam, yaitu: (1) efisiensi teknis, (2) efisiensi alokatif, dan (3) efisiensi ekonomi. Dikatakan efisien secara teknis (efisiensi teknis) kalau faktor produksi yang dipakai menghasilkan produksi maksimm. Efisiensi teknis akan tercapai pada saat elastisitas produksi (Ep) berada diantara nol dan satu $(0<$ Ep $<1)$. Dikatakan efisiensi harga atau efisiensi alokatif kalau nilai dari produk marginal sama dengan harga faktor produksi yang bersangkutan. Dikatakan efisiensi ekonomi kalau usaha pertanian tersebut mencapai efisiensi teknis dan sekaligus juga mencapai efisiensi harga. (Soekartawi, 2002)

\section{Konsep Efisiensi Teknis}

Ada beberapa defenisi efisiensi teknik dari suatu usahatani. Salah satu defenisi yang sering digunakan adalah nisbah antara produksi usahatani observasi dengan produksi dari fungsi produksi frontier (Battese dan Coelli , 1991 dalam Sukiyono, 2005). Secara ekonometrika, efisiensi teknik suatu usahatani tertentu, $\mathrm{TE}_{\mathrm{i}}$, didefenisikan sebagai nisbah dari rata-rata produksi usahatani $\mathrm{ke} I, \mathrm{u}_{\mathrm{i}}$ adalah positif, serta pada tingkat korbanan masukan $\left(\mathrm{x}_{\mathrm{i}}\right)$ dengan rata-rata produksi jika $u_{i}=0$, maka efisiensi teknik suatu usahatani ke-I dapat dirumuskan sebagai berikut :

$$
\mathrm{TE}_{\mathrm{I}}=\exp \left(-\mathrm{u}_{\mathrm{i}}\right)
$$

Perkiraan efisiensi teknik dari usahatani ke I memerlukan peubah acak yang tak terobservasi $\mathrm{u}_{\mathrm{i}}$

yang akan diperkirakan dari contoh yang diambil. Dengan demikian rumusan efisiensi yang digunakan adalah $\exp (-\hat{\mu})$ dimana $\hat{\mu}_{i}=E\left(\mu_{i} / E_{i}\right)$ dan $E_{i}=v_{i}-\mu_{i}$

Untuk mengukur tingkat efisiensi relatif suatu usahatani digunakan pendekatan parametrik melalui dugaan fungsi produksi frontier dimana keluaran dari suatu usahatani merupakan fungsi dari factor-faktor produksi, kesalahan acak dan inefisiensi.
Fungsi produksi frontier menggambarkan produksi maksimum yang dapat dihasilkan untuk sejumlah masukan produksi yang dikorbankan. Dengan model ini dimungkinkan untuk menduga atau untuk memperkirakan efisiensi relative suatu usahatani tertentu yang didapatkan dari hubungan antara produksi dan potensi produksi yang dapat dicapai.

Karakteristik yang cukup penting dari model produksi frontier untuk menduga efisiensi teknik adalah adanya pemisahan dampak dari goncangan peubah eksogen terhadap keluaran melalui kontribusi ragam yang menggambarkan efisiensi teknik ( giannakas et al, 2003 dalam Sukiyono, 2005).

Efisiensi teknik mengukur sampai sejauh mana seorang petani mengubah masukan menjadi keluaran pada tingkat dan faktor ekonomi dan tehnologi tertentu.

Fungsi Produksi Frontier adalah fungsi produksi yang dipakai untuk mengukur bagaimana fungsi sebenarnya terhadap posisi frontiernya. Karena fungsi produksi adalah hubungan fisik antara faktor produksi dan produksi, makaFungsi Produksi Frontier adalah hubungan fisik antara faktor produksi dan produksi pada frontier yang posisinya terletak pada isoquant. Garis isoquant ini adalah tempat kedudukan titik - titik yang menunjukkan titik kombinasipenggunaan masukan produksi yang optimal (Soekartawi, 1990:215).Pengertian efisiensi dalam produksi, bahwa efisiensi merupakan perbandingan antara output dan input berhubungan dengan tercapainya output maksimum dengan sejumlah input, artinya jika rasio outputbesar, maka efisiensi dikatakan semakin tinggi. Dapat dikatakan bahwa efisiensi adalah penggunaan input terbaik dalam memproduksi barang (Shone, Rinald, dalam Susantun, 2000). Farel membedakan efisiensi menjadi tiga, yaitu (1) efisiensi teknik, (2)efisiensialokatif, (3) efisiensi ekonomi. Timmer dalam Susantun (2000) mendefinisikan efisiensi teknis sebagai ratio input yang benarbenar digunakan dengan output yang tersedia.

Dalam penelitian ini, fungsi produksi yang digunakan adalah fungsi produksi stochas- 
tic frontier Cobb-Douglas.Pilihan terhadap bentuk fungsi produksi ini diambil berdasarkan alasan sebagai berikut : (1) bersifat homogeny sehingga dapat digunakan menurunkan fungsi biaya dual dari fungsi produksi, (2) lebih sederhana, dan (3) jarang menimbulkan masalah. Selain itu menurut Binici et al (1996), fungsi produksi stochastic frontier CobbDouglas telah digunakan secara luas dan teruji untuk mengkaji efisiensi produksi di NegaraNegara maju dan berkembang. Meski demikian ada beberapa kelemahan fungsi produksi CobbDouglas menurut Debertin (1986) diantaranya adalah : (1) tidak ada produksi maksimum, artinya sepanjang kombinasi input dinaikkan maka produksi akan terus naik sepanjang expansion pathnya, dan (2) elastisitas produksi tetap. Kelemahan ini membuat fungsi produksi Cobb-Douglas tidak bisa menggambarkan fungsi produksi neo-klasik.

Dalam fungsi produksi, factor-faktor yang seara langsung mempengaruhi kualitas produk yang dihasilkan adalah factor-faktor produksi yang digunakan seperti benih, pupuk, obat-obatan dan tenaga kerja.

\section{METODE PENELITIAN}

\section{Metode Pengambilan Sampel}

Pengambilan sampel dalam penelitian ini menggunakan metode cluster sampling terhadap kelompok tani peserta program Sekolah Lapang Pengelolaan Tanaman Terpadu (SLPTT) dan bukan peserta. Dari masingmasing populasi ditarik 3 kelompok tani secara acak sebagai sampel. Semua petani jagung yang masuk kedalam kelompok tani yang terpilih itulah yang menjadi sampel.

\section{Konsepsi Pengukuran Variabel}

Variabel-variabel yang diukur serta digunakan dalam penelitian ini adalah:

1. Produksi (kg/musim tanam) : Jagung yang dihasilkan dalam satu kali musim tanam. Sedangkan harga produksi dinyatakan dalam rupiah per kilogram.
2. Luas lahan (Ha) : Lahan yang ditanami jagung.

3. Jumlah Tenaga kerja (HOK), yaitu jumlah tenaga kerja yang digunakan dalam satu kali musim tanam (Setara hari kerja pria).

4. Jumlah Pupuk Urea (kg) : Jumlah pupuk yang digunakan dalam satu kali musim tanam..

5. Jumlah Pupuk Phonska (kg) : Jumlah pupuk yang digunakan dalam satu kali musim tanam.

6. Jumlah Benih (kg) : Jumlah benih yang digunakan dalam satu kali musim tanam.

7. Jumlah Pestisida (ltr) : Jumlah pestisida yang digunakan dalam pemberantasan hama dan penyakit.

Variabel-variabel yang digunakan untuk melihat factor-faktor yang mempengaruhi efisiensi teknis adalah :

1. Umur petani yang diukur dalam tahun

2. Tingkat pendidikan petani, yaitu tingkat pedidikan formal dari petani. Dalam penelitian ini tingkat pendidkan diukur dengan menggunakan variable dummy

3. Jumlah tanggungan keluarga , diukur dalam satuan orang.

\section{Metode Analisis Data}

1. Untuk menduga fungsi produksi usahatani jagung digunakan model persamaan fungsi produksi frontier sebagai berikut :

$$
\begin{aligned}
& \operatorname{Ln} Y=\beta 0+\beta 1 \ln X_{1}+\beta 2 \ln X_{2}+ \\
& \beta 3 \ln X_{3}+\beta 4 \ln X_{4}+\beta 4 l X_{5}+\beta 4 \ln X_{6}+v i^{-} \\
& u i
\end{aligned}
$$

Dimana:

$\mathrm{Y}=$ produksi Jagung ipilan kering $(\mathrm{kg})$

$\mathrm{X}_{1}=$ jumlah tenaga kerja yang digunakan (HOK)

$\mathrm{X}_{2}=$ jmlah pupuk urea yang digunakan $(\mathrm{kg})$

$\mathrm{X}_{3}=$ jumlah pupuk phonska yang digunakan

$\mathrm{X}_{4}=$ jumlah benih yang digunakan $(\mathrm{kg})$ 
$\mathrm{X}_{5}=$ Jumlah pestisida yang digunakan (liter)

$\mathrm{X}_{6}=$ Luas lahan yang ditanami jagung (ha)

$v i-u i=$ efek inefisiensi teknis dalam model

2. Untuk melihat factor-faktor yang mempengaruh efisiensi teknik usahatani jagung digunakan Analisis regresi dengan metode OLS. Model yang digunakan adalah sebagai berikut : $Y=\beta 0+\beta_{1} X_{1}+\beta_{2} X_{2}+\beta 3 D_{1}+\beta 3 D_{2}+\mu$

Dimana :

$Y=$ tingkat efisiensi

$X_{1}=$ umur

$X_{2}=$ jumlah tanggungan keluarga

$D_{1}=1$, jika SMP

$=0$, ijk lainnya

$D_{2}=1$, jika SMA

$=0$, jika lainnya

$\mu=$ variabel acak
Hasil analisis baik dengan metode OLS maupun metode MLE pada Tabel 2 menunjukan bahwa variable-variabel pupuk Phonska, benih, herbisida dan luas lahan bernilai positif sedangkan variable tenaga kerja dan pupuk urea bernilai negatif. Artinya produksi masih bisa ditingkatkan dengan menambah variable-variabel tersebut kecuali tenaga kerja dan pupuk urea. Secara statistik, keragaman tenaga kerja, pupuk, benih, herbisida dan luas lahan secara simultan mempengaruhi keragaman produksi padi sebesar 77,3\% sedangkan sisanya dipengaruhi oleh faktor lain di luar model. Secara parsial variabel benih dan herbisida dan tenaga kerja berpengaruh nyata pada produksi sedangkan variable pupuk urea, ponska dan luas lahan tidak berpengaruh nyata terhadap produksi. Hasil analisis menunjukkan bahwa penggunaan faktor produksi benih sudah efisien secara teknis. Dimana naiknya penggunaan benih sebesar $1 \%$ akan menaikkan

\section{HASIL DAN PEMBAHASAN}

Tabel 2. Pendugaan Fungsi Produksi pada Petani Peserta SLPTT dengan Menggunakan Metode OLS dan MLE

\begin{tabular}{|l|l|c|c|c|}
\hline \multirow{2}{*}{ Prediktor } & \multicolumn{2}{|c|}{ Metode OLS } & \multicolumn{2}{c|}{ Metode MLE } \\
\cline { 2 - 5 } & Dugaan & t-ratio & Dugaan & t-ratio \\
\hline Intersep & 3,560 & 4,10 & 3,007 & 3,36 \\
Tenaga kerja & $-0,000000002$ & $-1,54$ & $-0,000000002$ & $-1,16$ \\
Urea & $-0,059$ & $-0,57$ & $-0,153$ & $-1,51$ \\
Phonska & 0,0000000003 & 0,13 & 0,000000001 & 0,77 \\
Benih & 0,675 & 6,52 & 0,817 & 10,66 \\
Herbisida & 0,000000013 & 4,57 & 0,000000024 & 8,61 \\
Luas lahan & 0,199 & 1,53 & 0,191 & 1,74 \\
\hline
\end{tabular}

produksi sebesar $0.675 \%$. Rata-rata penggunaan benih pada petani responden adalah 15.43 $\mathrm{kg} / \mathrm{ha}$, masih lebih rendah dari yang dianjurkan oleh Danarti Dkk yaitu sebanyak $56 \mathrm{~kg} / \mathrm{ha}$. Faktor produksi tenaga kerja menunjukkan pengaruh yang negatif terhadap 
produksi ( $\mathrm{P}=0.05)$. Hasil analisis menunjukkan bahwa tingkat penggunaan faktor produksi tenaga kerja sudah tidak efisien secara teknis. Rata-rata penggunaan tenaga kerja pada petani responden yaitu 70.94 HOK. Ini menunjukkan bahwa penggunaan tenaga kerja pada usahatani jagung di Kecamatan Remboken relatif sudah berlebihan.

Faktor produksi pupuk khususnya pupuk urea cenderung menurunkan produksi. walaupun secara statistik menunjukkan pengaruh pupuk urea terhadap produksi tidak nyata ( $\mathrm{P}=0.231$ ) namun ada kecenderungan bahwa penggunaannya sudah tidak efisien lagi. Rata-rata penggunaan pupuk urea yaitu 194.13 $\mathrm{kg} / \mathrm{ha}$, sudah jauh melebihi dosis yang dianjurkan yaitu sebesar $100 \mathrm{~kg} / \mathrm{ha}$, hal ini berarti penggunaan pupuk urea pada petani responden sudah melebihi dari anjuran yang diberikan. Ini menunjukkan bahwa penggunaan pupuk urea perlu dikurangi. Faktor produksi pupuk khususnya pupuk phonska cenderung menaikkan produksi. Hasil pengujian statistik menunjukkan pengaruh penggunaan pupuk phonska terhadap produksi tidak nyata. Ratarata penggunaan pupuk phonska pada petani responden yaitu $173.2 \mathrm{Kg} / \mathrm{ha}$ masih lebih rendah dari yang dianjurkan. Faktor produksi herbisida secara statistik berpengaruh nyata terhadap produksi jagung.. Secara teknis tingkat penggunaan herbisida sudah efisien . Ratarata penggunaan herbisida yaitu sebesar 4.59 ltr/ha.

Hasil analisis terhadap petani yang bukan peserta SLPTT pada Tabel 3 menunjukkan bahwa variable benih, urea, phonska,herbisida dan luas lahan bernilai positif sementara tenaga kerja bernilai negatif. Ini berarti bahwa produksi masih bisa ditingkatkan dengan menambah variabel-variabel tersebut kecuali tenaga kerja. Secara statistik variabel benih dan herbisida berpengaruh sangat nyata terhadap produksi. $(\mathrm{p}<0,01)$

Tabel 3. Pendugaan Fungsi Produksi pada Petani Bukan Peserta SLPTTdengan Menggunakan Metode OLS dan MLE

\begin{tabular}{|l|l|l|l|l|}
\hline \multirow{2}{*}{\multicolumn{1}{|c|}{ Prediktor }} & \multicolumn{2}{c|}{ Metode OLS } & \multicolumn{2}{c|}{ Metode MLE } \\
\cline { 2 - 5 } & Dugaan & t-ratio & Dugaan & t-ratio \\
\hline Intersep & 2,998 & 3,459 & 3,084 & 3,358 \\
Tenaga kerja & $-0,000000015$ & $-6,649$ & $-0,000000015$ & $-0,000000015$ \\
Urea & 0,150 & 0,546 & 0,153 & 1,012 \\
Phonska & 0,000000002 & 0,648 & 0,000000002 & 0,000000002 \\
Benih & 0,846 & 3,749 & 0,846 & 8,46 \\
Herbisida & 0,0000000001 & 0,033 & 0,000000024 & 8,608 \\
Luas lahan & 0,096 & 0,443 & 0,096 & 0,096 \\
\hline
\end{tabular}

Faktor produksi tenaga kerja menunjukkan pengaruh yang negatif terhadap produksi Hasil analisis menunjukkan bahwa tingkat penggunaan faktor produksi tenaga kerja sudah tidak efisien secara teknis. Rata-rata penggunaan tenaga kerja pada petani responden yaitu 61.94 HOK. Jika dibandingkan dengan anjuran penggunaan tenaga kerja yang ada pada analisis usahatani jagung oleh Danarti dkk yaitu sebesar $57 \mathrm{HOK}$, maka penggunaan tenaga kerja pada usahatani jagung di Kecamatan Remboken relatif sudah berlebihan. 
Faktor produksi benih menunjukkan pengaruh yang positif yang berarti bahwa produksi masih dapat ditingkatkan melalui penambahan benih.. Hasil analisis menunjukkan bahwa penggunaan faktor produksi benih sudah efisien secara teknis. Rata-rata penggunaan benih pada petani responden ialah $30.63 \mathrm{~kg} / \mathrm{ha}$, jika dibandingkan dengan anjuran penggunaan benih pada analisis usahatani jagung yaitu sebanyak $56 \mathrm{~kg} / \mathrm{ha}$, maka rata-rata jumlah penggunaan benih di tingkat petani bukan peserta SLPTT masih lebih rendah dari dosis anjuran tersebut. Ini menunjukkan bahwa penggunaan benih masih bisa ditambah untuk mendapatkan hasil yang lebih baik.

Faktor produksi pupuk khususnya pupuk urea cenderung menaikkan produksi. Hasil pengujian statistik menunjukkan pengaruh penggunaan pupuk urea terhadap produksi tidak nyata. Tingkat penggunaan pupuk urea sudah efisien secara teknis. Rata-rata penggunaan pupuk urea yaitu $131.8 \mathrm{~kg} / \mathrm{ha}$, masih lebih rendah dari dosis anjuran yaitu $150 \mathrm{~kg} / \mathrm{ha}$, hal ini berarti penggunaan pupuk urea masih bisa ditambah.

Faktor produksi pupuk phonska cenderung menaikkan produksi. Hasil pengujian statistik menunjukkan pengaruh penggunaan pupuk phonska terhadap produksi tidak nyata . Berdasarkan pada nilai elastisitas menunjukkan bahwa tingkat penggunaaan pupuk phonska sudah efisien secara teknis. Rata-rata penggunaan pupuk phonska pada petani responden yaitu $113.3 \mathrm{~kg} / \mathrm{ha}$.

Faktor produksi herbisida cenderung menaikkan produksi. Hasil pengujian secara statistik menunjukkan pengaruh herbisida terhadap produksi tidak nyata. Berdasarkan nilai elastisitas menunjukkan bahwa tingkat penggunaan herbisida sudah efisien secara teknis. Rata-rata penggunaan herbisida yaitu sebesar 6.15 ltr/ha.

Luas lahan cenderung menaikkan produksi. Penggunaan lahan sudah efisien secara teknis. Rata-rata penggunaan luas lahan pada petani yang bukan peserta adalah 1.158 Ha.

Jika dibandingkan antara kelompok tani peserta program SLPTT dengan kelompok tani yang bukan peserta program SLPTT maka tampak bahwa tingkat efisiensi penggunaan tenaga kerja, pupuk phonska, benih, herbisida dan luas lahan cenderung sama namun tingkat efisiensi penggunaan pupuk urea berbeda. Penggunaan dosis urea pada kelompok peserta SLPTT jauh lebih tinggi dari kelompok bukan peserta SLPTT bahkan melebihi dari yang dianjurkan sehingga peggunaannya sudah tidak efisien lagi.

\section{Analisis Efisiensi Teknis}

Efisiensi teknis dianalisis dengan menggunakan model fungsi produksi stochastic frintier. Nilai indeks efisiensi teknis hasil analisis dikategorikan efisien jika lebih besar dari 0,8. Sebaran petani peserta SLPTT menurut nilai efisiensi dapat dilihat pada Tabel 4.

Tabel 4 menunjukkan bahwa efisiensi teknis terendah dari kelompok petani peserta SLPTT adalah 0,20, sedangkan efisiensi teknis tertinggi adalah 0,99. Ini menunjukkan bahwa kemampuan petani dalam mengelolah usahatani jagung dari kelompok ini sangat bervariasi. Walaupun Sebaran nilai efisiensi teknis petani peserta SLPTT menunjukkan bahwa 71,43\% dari jumlah petani memiliki nilai efisiensi teknis lebih besar dari 0,8 yang menunjukkan bahwa sebagian besar usahatani jagung yang diusahakan petani peserta SLPTT sudah efisien secara teknis namun hasil tersebut tidak sesuai dengan yang diharapkan. Seharusnya dengan adanya pemberian pengetahuan tentang tehnologi budidaya disertai dengan sekolah lapang, maka kemampuan petani dalam mengelola usahataninya dan kemampuan dalam menentukan tingkat penggunaan faktor produksi secara tepat akan semakin meningkat.

Sebaran petani bukan peserta SLPTT menurut nilai efisiensi teknis dapat dilihat pada Tabel 5. 
Tabel 4. Sebaran Nilai Efisiensi Teknis Petani Responden Peserta SLPTT

\begin{tabular}{|c|c|c|}
\hline \multirow{2}{*}{ Interval } & \multicolumn{2}{|c|}{ Efisiensi Teknis } \\
\cline { 2 - 3 } & Jumlah & \% \\
\hline$<0,8$ & 12 & 33,33 \\
\hline $0,8-0,89$ & 14 & 38,10 \\
\hline$>0,89$ & 16 & 100,00 \\
\hline Total & 42 & 0,80 \\
\hline Rata-rata & & 0,20 \\
Minimum & & 0,99 \\
Maksimum & & \\
\hline
\end{tabular}

Tabel 5. Sebaran Nilai Efisiensi Teknis Petani Responden Bukan Peserta SLPTT

\begin{tabular}{|c|c|c|}
\hline \multirow{2}{*}{ Interval } & \multicolumn{2}{|c|}{ Efisiensi Teknis } \\
\cline { 2 - 3 } & Jumlah & 0 \\
\hline$<0,8$ & 0 & 0,02 \\
\hline $0,8-0,89$ & 51 & 0,98 \\
\hline$>0,89$ & 52 & 100,00 \\
\hline Total & & 0,92 \\
\hline Rata-rata & & 0,89 \\
Minimum & \multicolumn{2}{c}{} \\
Maksimum & \multicolumn{2}{c}{} \\
\hline
\end{tabular}

Jika dibandingkan antara peserta dan

Tabel 5 menunjukkan nilai efisiensi teknis terendah adalah 0,89 dan yang tertinggi adalah 0,94. Artinya efisiensi teknis dari masingmasing individu petani hampir sama. Sebaran nilai efisiensi teknis petani peserta SLPTT menunjukkan bahwa $100 \%$ petani responden bukan peserta SLPTT memiliki nilai efisiensi teknis lebih besar dari 0,8. Ini menunjukkan bahwa usahatani jagung yang diusahakan petani bukan peserta SLPTT sudah efisien secara teknis. bukan peserta SLPTT ternyata tingkat efisiensi teknis usahatani yang diusahakan oleh petani yang tidak mengikuti program SLPTT lebih tinggi dari yang mengikuti SLPTT, walaupun nilai efisiensi teknis maksimum yang dicapai oleh petani peserta SLPTT lebih tinggi dari yang bukan peserta SLPTT. Hasil tersebut tidak sesuai dengan yang diharapkan. Dengan mengikuti sekolah lapang, diharapkan petani akan lebih banyak memperoleh pengetahuan yang dapat meningkatkan kemampuan dalam mengadopsi tehnologi dan dapat menggunakan input secara proporsional. Hasil tersebut 
menunjukkan bahwa program SLPTT belum efektif.

Untuk mengetahui faktor-faktor yang berpengaruh terhadap efisiensi teknis, digunakana analisis regresi. Hasil analisis regresi menunjukkan bahwa umur dan tingkat pendidikan berpengaruh negatif terhadap tingkat efisiensi teknis, sedangkan jumlah tanggungan berpengaruh positif terhadap tingkat efifiensi teknis.

Tabel 6. Hasil Analisis Regresi Faktor-faktor yang Mempengaruhi Tingkat Efisiensi Teknis

\begin{tabular}{|l|c|c|}
\hline Variabel & Dugaan & t-ratio \\
\hline Intersep & 0,8416 & 8,71 \\
Umur & $-0,0008$ & $-0,51$ \\
Jumlah tanggungan & 0,0184 & 1,28 \\
Tingkat pendidikan: & & \\
SLTP & $-0,0053$ & $-0,15$ \\
SLTA & $-0,0804$ & $-1,81$ \\
\hline
\end{tabular}

Umur berpengaruh negatif menunjukkan bahwa semakin tua umur petani cenderung tidak efisien dalam berproduksi dan dalam menggunakan input-input produksi. Hal ini karena seiring dengan peningkatan usia petani maka kemampuan bekerja yang dimiliki, daya juang dalam berusaha, keinginan dalam menanggung resiko dan keinginan menerapkan inovasi-inovasi baru semakin berkurang. Tingkat pendidikan berpengaruh negatif terhadap efisiensi. Hasil tersebut tidak sesuai yang diharapkan. Jumlah tanggungan cenderung berpengaruh positif terhadap tingkat efisiensi.
Hal ini menunjukkan bahwa dengan semakin banyak tanggungan, petani berusaha untuk meningkatkan kinerjanya agar hasil yang diperoleh semakin meningkat untuk memenuhi kebutuhan keluarga.

\section{KESIMPULAN DAN SARAN}

\section{Kesimpulan}

1. Produksi Jagung secara nyata dipengaruhi oleh tenaga kerja, benih dan herbisida.

2. Sebagian besar usahatani jagung yang diusahakan petani telah efisien secara teknis. Tingkat efisiensi teknis petani bukan peserta SLPTT lebih tinggi dari petani peserta SLPTT.

3. Jumlah tanggungan dan tingkat pendidikan secara signifikan mempengaruhi tingkat efisiensi secara teknis

4. Umur berpengaruh negatif terhadap efisiensi teknis, namun pengaruhnya tidak signifikan.

\section{Saran}

Perlu merumuskan kembali model Sekolah Lapang Pengembangan Tanaman Terpadu yang lebih efektif untuk meningkatkan kemampuan petani dalam menge-lola usahataninya 


\section{DAFTAR PUSTAKA}

Anonimous, 2010. Sekolah Lapang Pengelolaan Tanaman Terpadu (SLPTT) Jagung. Gorontalo.litbang.deptan.go.id. diakses September 2010.

Anonimous, 2010.. Tolak ukur keberhasilan SLPTT. Gerbangtani.blogspot.com Diakses September 2010.

Apriyantono, A. 2008. Panduan Pelaksanaan Sekolah Lapang Pengelolaan Tanaman Terpadu (SL-PTT) Jagung.

Coelli, T. 1996. A Guide to FRONTIER Version 4.1 : A Computer Program for Stochastic Frontier Production and Cost Function Estimation Centre for Efficiencyand Productivity Analysis, University of New England, Armidale

Debertin, D. L. 1986. Agricultural Production Economics .Macmillan Publishing Company, New York

Farrel, M. J. 1957. The Measurement of Productive Efficiency. Journal of Royal Statistic Society, Series A.

Gujarati. D. 1988. Ekonometrika Dasar. Erlangga.

Hernanto, F. 1991. Ilmu Usahatani. Penebar Swadaya. Jakarta 1993.Prinsip Dasar Ekonomi Pertanian.Teori dan Aplikasi. Rajawali Pers, Jakarta .2002.Teori Ekomoni Produksi. UI.Press.Jakarta

Mosher, A. 1991. Menggerakan dan Membangun Pertanian. CV Yasaguna. Jakarta.
Mubyarto, 1989. Pengantar ekonomi pertanian. LP3ES, Jakarta.

Rahardja,P.2008. Teori Ekonomi Mikro. FEUI. Jakarta.

Soekartawi, 1996. Analisis Usahatani. UI.Press.Jakarta.

Sukiyono, S., 2005. Faktor Penentu Tingkat Efisiensi Teknik Usahatani Cabai Merah di Kecamatan Selupu Rejang, Kabupaten Rejang Lebong. Jurnal Agro Ekonomi Volume 23 No.2. Oktober 2005.

Zulkifli,A.2009. Analisis Efisiensi Penggunaan Faktor-Faktor Produksi Pada Usaha tani jagung (Studi kasus petani jagung di Kel. Panreng Kec. Baranti Kab.Sidrap).

(http://www.tenangjaya.com/index.ph p/relevan-artikel/analisis-efisiensipenggunaan.htm).diakses September 2010 . 